Medieval Italy 
THE MID DLE AGES SERIES

Ruth Mazo Karras, Series Editor

Edward Peters, Founding Editor

A complete list of books in the series is available from the publisher. 


\title{
Medieval Italy
}

Texts in Translation

\author{
Edited by \\ KATHERINE L. JANSEN, \\ JOANNA DRELL, \\ and
}

FRANCES ANDREWS

\section{$\overline{\text { PENN }}$}

University of Pennsylvania Press

Philadelphia 
Copyright (C) 2009 University of Pennsylvania Press

All rights reserved. Except for brief quotations used for purposes of review or scholarly citation, none of this book may be reproduced in any form by any means without written permission from the publisher.

\section{Published by}

University of Pennsylvania Press

Philadelphia, Pennsylvania I9IO4-4II2

Printed in the United States of America on acid-free paper

IO $9 \begin{array}{lllllllll}9 & 8 & 7 & 6 & 5 & 4 & 3 & 2 & \text { I }\end{array}$

Library of Congress Cataloging-in-Publication Data

Medieval Italy : texts in translation / edited by Katherine L. Jansen, Joanna Drell, and Frances Andrews.

p. $\quad \mathrm{cm}$. - (The Middle Ages series)

ISBN: 978-0-8I22-4I64-8 (acid-free paper)

Includes bibliographical references and index.

I. Italy-History-476-I268-Sources. 2. Italy-HistoryI268-I492-Sources. I. Jansen, Katherine Ludwig, I957-.

II. Drell, Joanna H., I965-. III. Andrews, Frances.

DG50I.M535 2009

$94^{\prime} . \mathrm{OI}-\mathrm{dc2} 2$

2008051233 